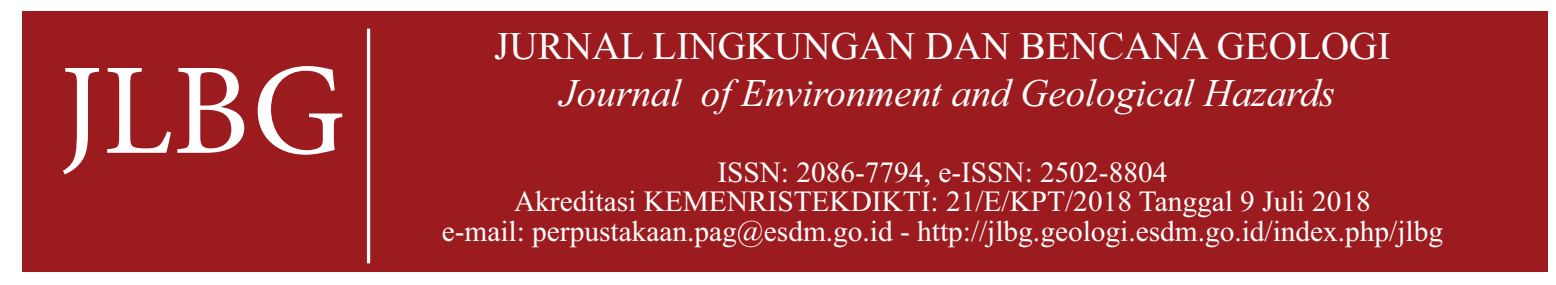

\title{
Pemodelan Aliran Bahan Rombakan \\ di Kecamatan Sambelia, Kabupaten Lombok Timur, Nusa Tenggara Barat
}

\author{
Debris Flow Modelling in Sambelia District, East Lombok Regency, \\ West Nusa Tenggara
}

\author{
Yohandi Kristiawan dan Sumaryono \\ Pusat Vulkanologi dan Mitigasi Bencana Geologi, Badan Geologi \\ Jalan Diponegoro No. 57, Kota Bandung, Indonesia \\ e-mail: yohandi.kristiawan@vsi.esdm.go.id \\ Naskah diterima 13 April 2018, selesai direvisi 22 November 2019, dan disetujui 16 April 2020
}

\begin{abstract}
ABSTRAK
Aliran bahan rombakan adalah fenomena yang terjadi, ketika percampuran air, lumpur, dan kerikil sampai bongkah mengalir dengan kecepatan tinggi menuruni lereng. Aliran ini memiliki viskositas dan kecepatan yang tinggi, sehingga bersifat sangat merusak karena mengangkut material yang dilalui di sepanjang sungai sehingga volume dan energinya kian meningkat. Oleh karena itu, aliran bahan rombakan dapat merusak infrastruktur dan mengakibatkan jatuhnya korban jiwa. Aliran bahan rombakan merupakan jenis gerakan tanah yang sering terjadi di Kecamatan Sambelia, Kabupaten Lombok Timur, Nusa Tenggara Barat. Kejadian aliran ini terjadi selama kurun 10 tahun terakhir yaitu pada tahun 2006, 2012, 2014, dan 2017. Dampaknya menyebabkan banyak korban jiwa dan beberapa jembatan utama roboh sehingga jalur transportasi terputus serta sebagian masyarakat terpaksa mengungsi. Topografi di daerah Sambelia yang berupa perbukitan terjal dengan hulu sungai yang sempit menyebabkan beberapa daerah aliran sungai di wilayah ini rentan terjadi bendungan alam. Berdasarkan interpretasi citra, daerah Sambelia merupakan kipas aluvial. Salah satu upaya mitigasi terhadap ancaman aliran bahan rombakan adalah dengan membuat pemodelan. Untuk memodelkannya digunakan Rapid Mass Movement Simulation (RAMSS). Pemodelan dilakukan dengan memasukkan parameter-parameter tertentu seperti volume, friksi, DEM, dll. Hasil pemodelan ini berupa zonasi daerah bahaya aliran bahan rombakan, yang diharapkan dapat menjadi salah satu rujukan dalam mitigasi bencana aliran bahan rombakan di Kecamatan Sambelia.
\end{abstract}

Kata kunci: aliran bahan rombakan, pemodelan, RAMSS, Sambelia

\section{ABSTRACT}

Debris flow is a phenomenon in which a mixture of large quantities of water, mud, and gravel flows down stream in high speed moving down the slope. Due to its high density and velocity, debris flow is very devastating, because it carries along every things on its path that increases its volume and energy, hence it can destroy settlements, bridges, infrastructures as well as loss of lives. The debris flow is a typical mass movement was frequently occurred in Sambelia district, East Lombok Regency, West Nusa Tenggara. The debris flows often occur during the last 10 years in 2006, 2012, 2014, and 2017. Its flows caused many casualties and several major bridges collapsed or broken also transportation were cut off and some people were forced to evacuate. Topography in the area of Sambelia consist of steep hills with narrow upstream makes some areas of the river vulnerable to the landslide dam. Based on remote sensing interpretation Sambelia area is alluvial fan area. One of the mitigation effort is debris flow modelling using Rapid Mass Movement. The Modelling is set up by inputing certain parameters such as volume, friction, DEM, etc. The results are the affected zones or hazard zones which can be used as a reference in landslide mitigation in Sambelia District.

Keywords: flow, modelling, RAMMS, Sambelia 


\section{PENDAHULUAN}

Aliran bahan rombakan (debris flow) adalah fenomena campuran air, lumpur, dan kerikil sampai bongkah mengalir dengan kecepatan tinggi menuruni lereng (Varnes, 1978). Aliran ini umumnya terbentuk akibat curah hujan yang tinggi yang mengikis dan memobilisasi tanah atau batuan lepas di lereng curam. Aliran bahan rombakan berbeda dengan banjir berdasarkan komponennya. Wilford drr. (2004) menyebutkan bahwa aliran bahan rombakan mempunyai konsentrasi sedimen lebih dari $20 \%$ sedangkan banjir normal kurang dari 20\%. Selain itu, aliran bahan rombakan mampu membawa klastika berukuran besar dan umumnya mempunyai imbrikasi yang buruk. Biasanya aliran ini akan membuat struktur endapan berupa morfologi yang dikenal sebagai kipas aluvial. Aliran bahan rombakan di Indonesia sering disebut banjir bandang. Banjir Bandang adalah banjir yang datang secara tiba-tiba dengan debit air besar yang disebabkan terbendungnya aliran sungai. Sambelia merupakan salah satu kecamatan di
Kabupaten Lombok Timur, Nusa Tenggara Barat. Secara geografis, Sambelia terletak di sebelah timur laut Pulau Lombok dengan morfologi sebelah barat terjal berupa pegunungan yang berubah melandai ke hilir di sebelah timur (Gambar 1). Topografi di daerah Sambelia berupa perbukitan terjal dengan hulu sungai yang sempit dan bagian bawahnya merupakan kipas aluvial. Sehingga beberapa daerah aliran sungai di wilayah ini sangat rentan terjadi aliran bahan rombakan. Kejadian aliran ini sering terjadi selama kurun sepuluh (10) tahun terakhir yaitu pada tahun 2006, 2012, 2014, dan 2017 (Tabel 1). Dampaknya menyebabkan banyak korban jiwa dan beberapa jembatan utama roboh sehingga jalur transportasi terputus serta sebagian masyarakat terpaksa mengungsi.

Daerah yang terlanda bencana umumnya terletak di bagian kaki lereng sebelah timur kompleks perbukitan Gunung Sengkor (+1500 m). Di bagian lereng perbukitan ini terdapat sembilan sungai di antaranya Kokok Sambelia, Kokok Lepok, Kokok Rajak, Kokok Hangat, Kokok

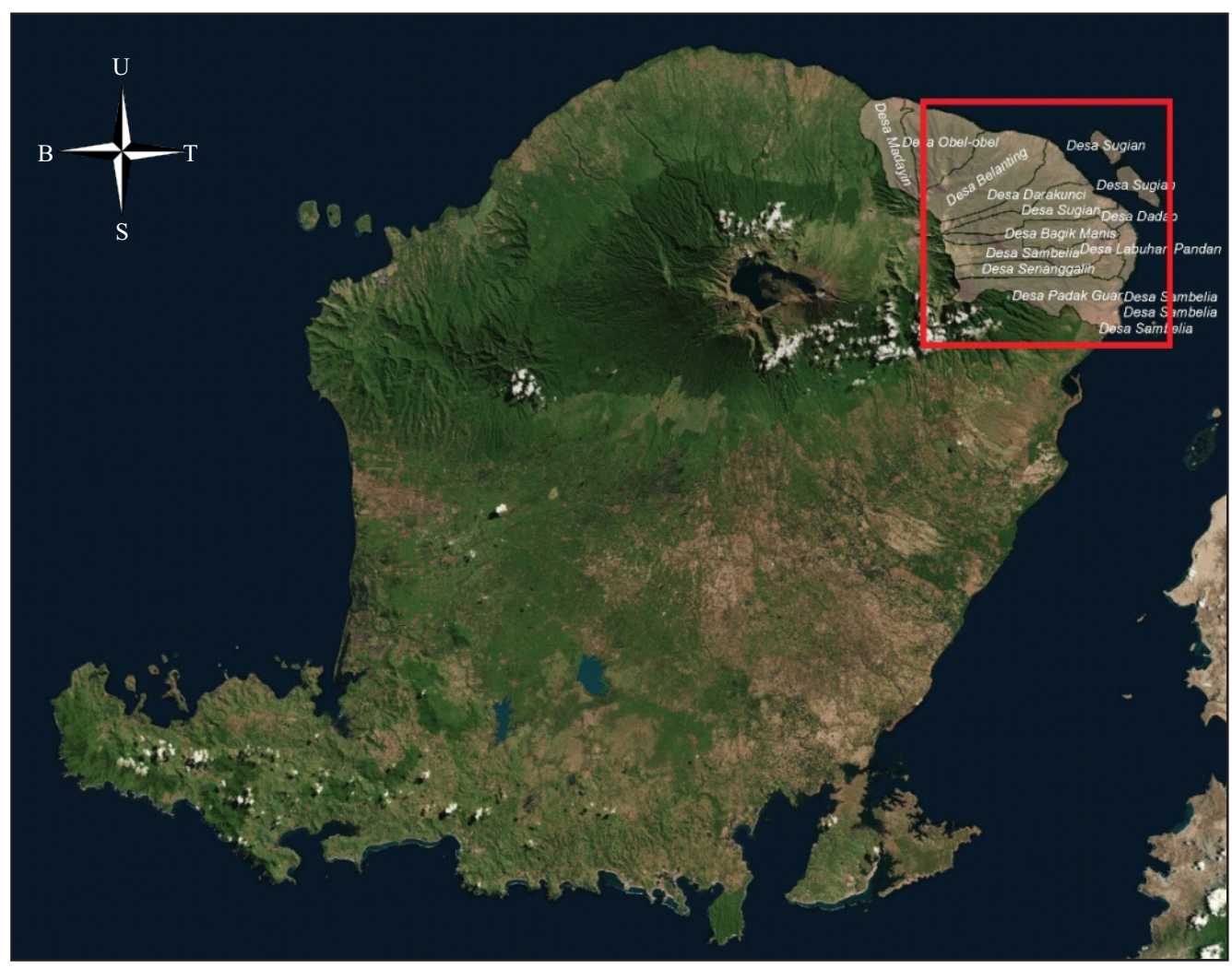

Gambar 1. Peta area penelitian pemodelan banjir bandang Sambelia (kotak merah). 
Tabel 1. Kejadian aliran bahan rombakan di Kecamatan Sambelia selama sepuluh tahun terakhir

\begin{tabular}{|c|c|c|}
\hline Waktu & Lokasi & Dampak Kejadian \\
\hline 21 Januari 2006 & $\begin{array}{l}\text { alur Sungai Belanting, } \\
\text { Desa Belanting, Desa } \\
\text { Sugihan, Desa Obel-Obel }\end{array}$ & $\begin{array}{l}1 \text { orang meninggal dunia, } 14 \text { orang luka-luka, } 416 \text { rumah rusak berat, } 300 \text { rumah rusak } \\
\text { ringan, serta beberapa sarana dan pra sarana rusak (Purnomo, drr, 2006). }\end{array}$ \\
\hline 13 Maret 2012 & $\begin{array}{l}\text { Kokok Pasiran, Kokok } \\
\text { Sepang, Kokok Nangka, } \\
\text { dan Kokok Salut }\end{array}$ & $\begin{array}{l}\text { - } 360 \text { rumah yang terletak di bantaran empat sungai rusak berat sementara } 1080 \\
\text { rusak ringan. } \\
58 \mathrm{KK} \text { atau } 289 \text { jiwa mengungsi ke tempat yang aman. } \\
\text { Jalan provinsi sepanjang } 50 \mathrm{~m} \text {, jalan kabupaten } 1500 \mathrm{~m} \text {, dan jalan desa } \\
\text { sepanjang } 3100 \mathrm{~m} \text { mengalami kerusakan karena tergenang air dan lumpur } \\
\text { setinggi } 0,5-10 \mathrm{~m} \text { sehingga di } 3 \text { lokasi tersebut terdapat jalur jalan amblas } \\
\text { (Darsoatmodjo dan Rukmana, 2012). }\end{array}$ \\
\hline Januari 2016. & $\begin{array}{l}\text { Jl. Raya Mataram - } \\
\text { Sembalun }\end{array}$ & Aliran bahan rombakan memutus jalan raya km 78,4 - 80 Mataram - Swela - Sembalun \\
\hline Februari 2017 & $\begin{array}{l}\text { Desa Belanting, Sugian, } \\
\text { Darakunci, Sambelia }\end{array}$ & $\begin{array}{l}4 \text { desa terisolasi akibat banjir bandang. Empat desa itu adalah Sambelia, Sugian, } \\
\text { Darakunci, dan Belanting }\end{array}$ \\
\hline
\end{tabular}

Tibu Dalam, Kokok Pasiran dan Kokok Salut, yang semuanya bermuara ke arah pantai di Selat Sugian dengan pola aliran sungai subparalel. Kemiringan lereng di bagian atas daerah bencana umumnya terjal hingga sangat terjal antara $20^{\circ}-35^{\circ}$ dan setempat $>45^{\circ}$. Sedangkan daerah yang terlanda aliran bahan rombakan mempunyai ketinggian antara 3 - $150 \mathrm{~m}$ dpl.

Berdasarkan Peta Geologi Regional Lembar Lombok (Mangga drr., 1994), daerah Sambelia termasuk dalam batuan gunungapi tak terpisahkan, terdiri dari: lava, breksi dan tuf, yang merupakan hasil kegiatan gunungapi Pusuk - Nangi (Qhv pn) dan Rinjani (Qhv r) yang takterpisahkan (Gambar 2).

Luthfi, drr. (2008) memetakan aliran bahan rombakan di daerah Lombok Timur sebelumnya. Zonasi aliran ini dimuat bersama dengan Peta Zona Kerentanan Gerakan Tanah Lombok Timur. Secara umum daerah penyelidikan termasuk dalam Zona Kerentanan Tanah Tinggi (Gambar 3) terutama di bagian perbukitan dan hulu sungai. Artinya di daerah ini dapat terjadi gerakan tanah jika curah hujan di atas normal, terutama pada daerah yang berbatasan dengan lembah sungai, gawir, tebing jalan, atau jika lereng mengalami gangguan tinggi, dan gerakan tanah lama dapat aktif kembali. Sedangkan di bagian tengah dan hilir termasuk dalam zona menengah dan rendah (daerah pantai). Namun, untuk daerah aliran sungai beberapa di antaranya masuk dalam zona aliran bahan rombakan. Sungai-sungai seperti Kokok Nangka, Kokok Padamekan, dan Sambelia termasuk dalam zona tersebut. Sehingga meskipun beberapa daerah termasuk dalam zona kerentanan tanah rendah seperti di hilir sungai tetapi bisa saja daerah tersebut masuk dalam Zona Aliran Bahan Rombakan.

Maksud pemodelan aliran bahan rombakan di Sambelia ini adalah untuk mengetahui area landaan aliran bahan rombakan. Sedangkan tujuannya untuk membuat model landaan bencana yang dapat dijadikan kajian dalam mitigasi bencana gerakan tanah di Sambelia.

\section{METODE PENELITIAN}

Metode yang dilakukan adalah pengamatan langsung kondisi sungai di lapangan dari bagian hulu hingga hilir, kondisi batuan, kejadian longsor sebelumnya, hingga dimensi sungai. Tahapan pekerjaan sesuai dengan diagram alir (Gambar 4), yakni dimulai dari kajian pustaka untuk mendapatkan data data sekunder serta inventarisasi kejadian aliran bahan rombakan terdahulu di Sambelia. Tahap berikutnya adalah penyelidikan lapangan ke sungai sungai di daerah Sambelia untuk mengetahui karakteristik morfologi dan endapan sungai sehingga didapat- 


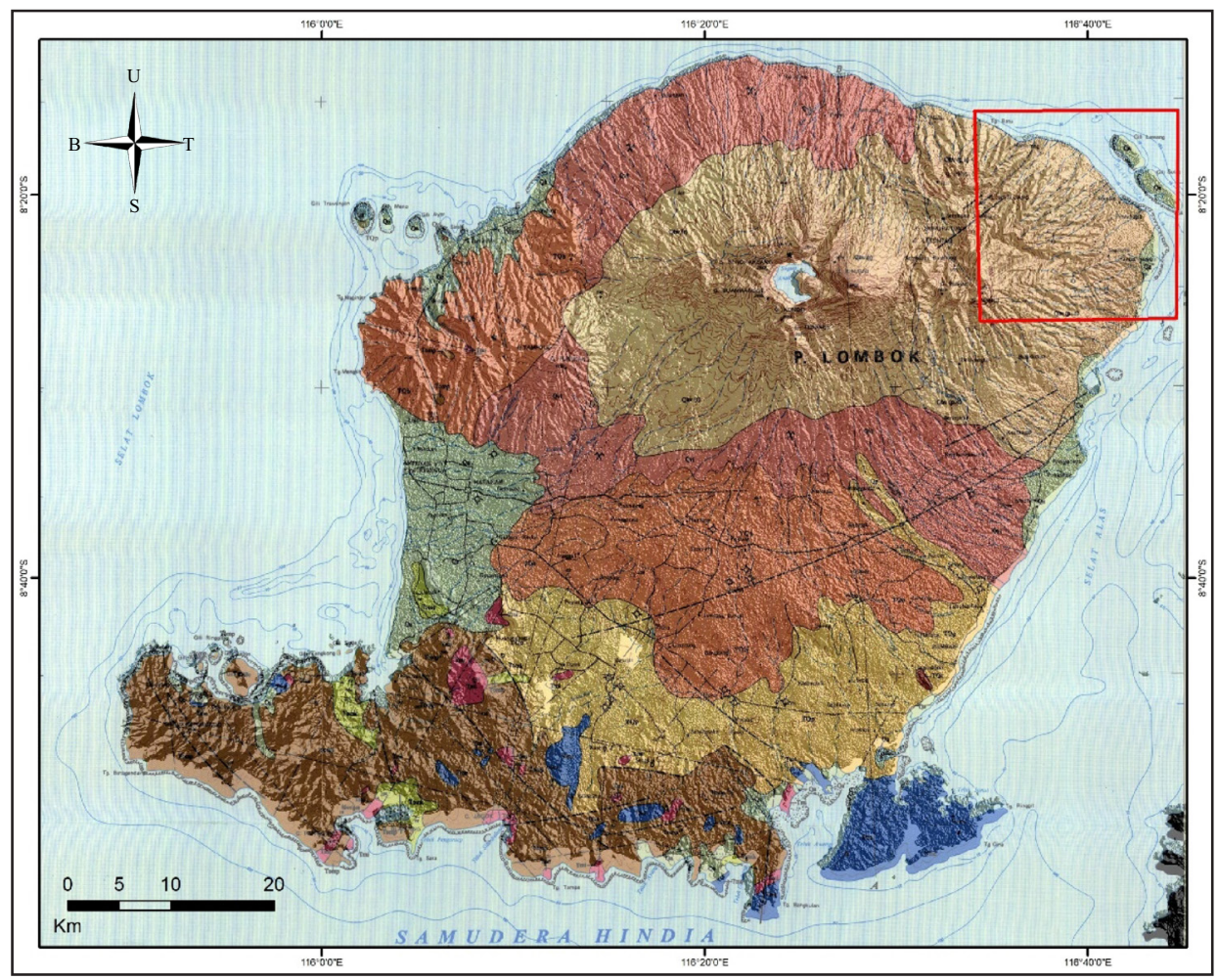

Gambar 2. Peta Geologi Pulau Lombok (area penelitian pada kotak merah) (Mangga drr, 1994).

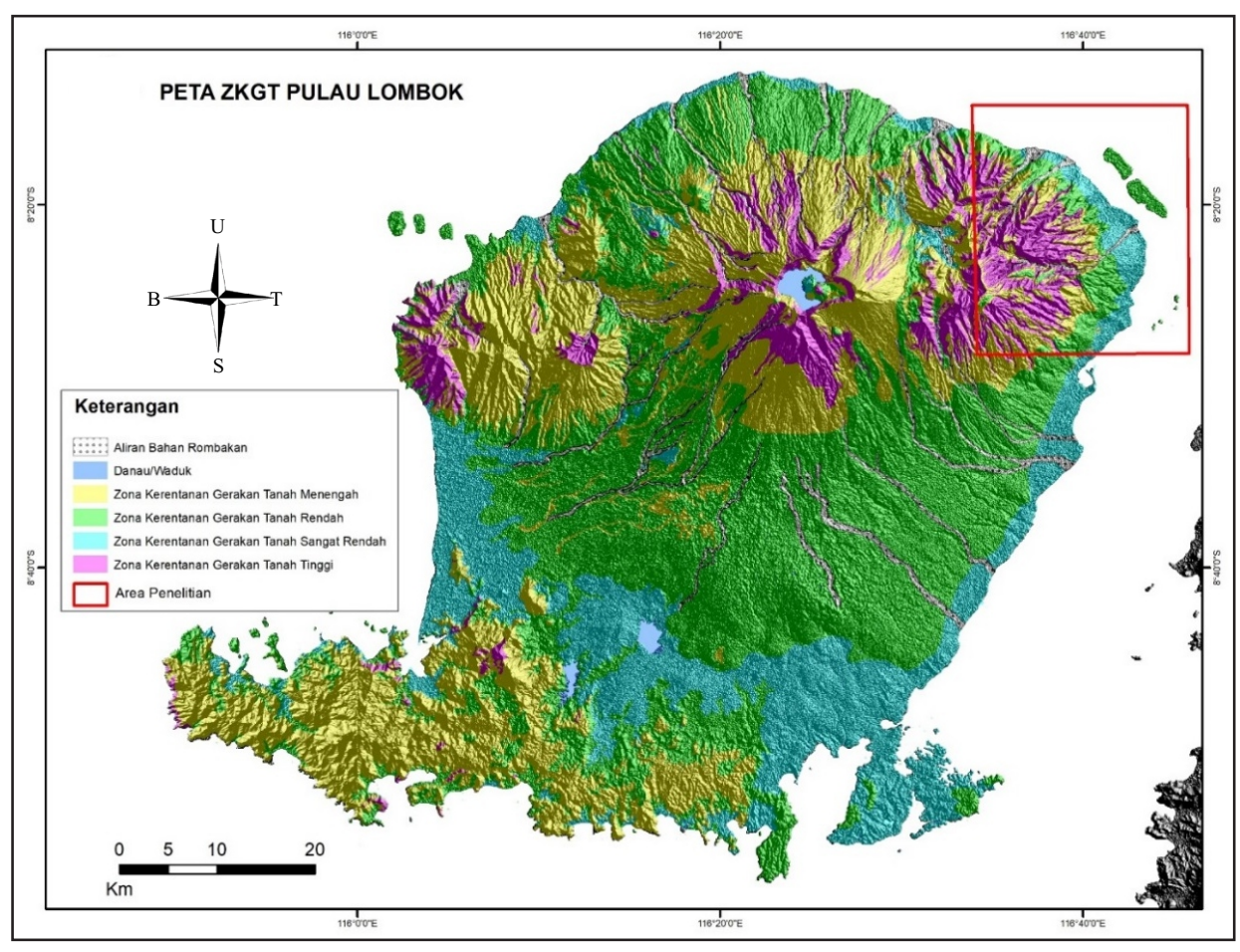

Gambar 3. Peta ZKGT Pulau Lombok (modifikasi dari Luthfi drr, 2008).

kan sungai mana saja yang rentan aliran bahan rombakan dan layak untuk dimodelkan. Setelah itu, dilanjutkan dengan melakukan pemodelan aliran bahan rombakan menggunakan perangkat 


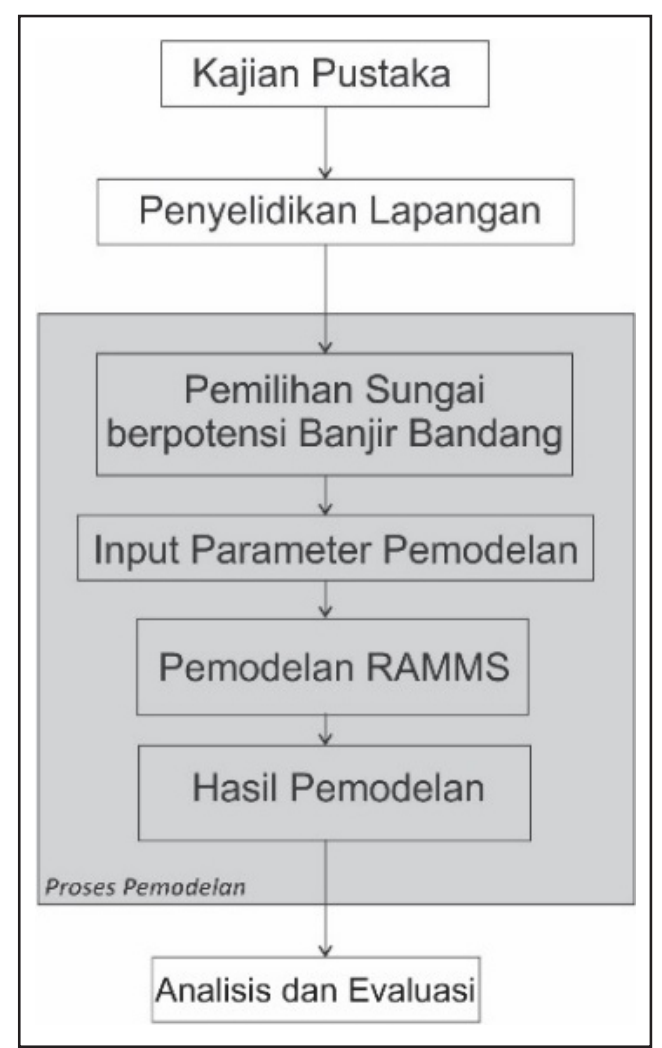

Gambar 4. Diagram alir penelitian

lunak RAMMS (Rapid Mass Movement Simulation). Pemodelan dengan RAMMS dilakukan dengan memasukkan parameter pemodelan yang sudah ditentukan sebelumnya. Hasil pemodelan adalah berupa zona daerah bahaya yang dibandingkan dengan Zona Rentan Aliran Bahan Rombakan pada Peta Zona Kerentanan Gerakan Tanah.

RAMMS adalah perangkat lunak untuk pemodelan numerik dinamik yang didesain awalnya untuk pemodelan longsoran salju (snow avalanches) (Christen drr., 2010) yang kemudian diaplikasikan untuk pemodelan aliran massa yang lain seperti lahar (Luna, 2007) dan aliran bahan rombakan (Kowalski, 2008). RAMMS dikembangkan oleh tim ahli dari WSL Institute for Snow and Avalanche Research SLF dan the Swiss Federal Institute for Forest, Snow, and Landscape Research WSL.

RAMMS Debris Flow dikembangkan untuk mensimulasikan aliran bahan rombakan pada morfologi/medan yang kompleks. Model
RAMMS sudah digunakan di Swiss dan belahan dunia lain untuk analisis bahaya debris flow dan membantu mendesain mitigasi bencana. RAMMS menggabungkan metode solusi numerik dengan input fitur yang bermanfaat dan visualisasi yang mudah digunakan. RAMMS menggunakan model kontinum aliran fluida Voellmy-Salm (Salm, 1993) berdasarkan hukum aliran fluida Voellmy, juga menjelaskan aliran bahan rombakan sebagai hidrolika berdasarkan kedalaman rata-rata model kontinum. Model ini membagi resistansi friksi menjadi dua yaitu dry-Coulomb type friction yang berskala dengan tegangan normal dan viscous-turbulent friction $(\xi)$. (koefisien $\xi$ ). Sehingga persamaan friksi S (Pa) menjadi :

$S=\mu \rho H g \cos \phi+\frac{\rho g U^{2}}{\xi}$

$\rho$ : berat jenis aliran

$\phi:$ sudut kelerengan

$\mathrm{g}:$ percepatan gravitasi

$\mathrm{H}$ : tinggi aliran

$\mathrm{U}$ : kecepatan aliran

Persamaan tersebut terus dikembangkan hingga RAMMS versi 1.6.2 dimodifikasi dengan menambahkan kohesi (C). Sehingga persamaannya berubah menjadi :

$$
S=\mu N+(1-\mu) C-(1-\mu) \operatorname{Cexp}\left(\frac{-N}{C}\right)+\frac{\rho g U^{2}}{\xi} \cdots
$$

Input data RAMMS meliputi data DEM (Digital Elevation Model), daerah inisiasi, parameter gesekan, volume, dan beberapa parameter lain (debit aliran, kecepatan, dan kohesi) tergantung aliran yang ingin dimodelkan. Untuk daerah inisiasi terdapat dua pilihan menggunakan block release atau hydrograph. Block release dipakai untuk aliran debris sederhana atau dangkal tanpa kanal. Sedangkan hydrograph lebih cocok untuk aliran debris besar berkanal seperti banjir bandang. 


\section{HASIL DAN PEMBAHASAN}

Kegiatan lapangan pemodelan aliran bahan rombakan di Sambelia dipusatkan pada beberapa aliran sungai yang pernah terjadi atau berpotensi. Sungai-sungai tersebut di antaranya adalah Kokok Padamekan, Kokok Nangka, dan Kokok Sambelia, (Gambar 5). Dari kenampakan citra terlihat bahwa secara umum daerah Sambelia merupakan kipas aluvial yang kemungkinan terbentuk akibat aliran bahan rombakan di masa lampau.

Padamekan terletak di Desa Belanting, Sambelia. Sungai ini pernah mengalami kejadian aliran bahan rombakan besar pada tahun 2006. Karakter morfologinya yang berbukit bukit dan berhulu sempit serta jejak kejadian banjir bandang terdahulu membuat sungai ini berpotensi untuk mengulangi kejadian bencana yang sama.

Kokok Padamekan mempunyai panjang aliran kurang lebih $10 \mathrm{~km}$ dari bagian paling hulu hingga hilir bibir pantai. Sungai ini terlihat kering di musim kemarau. Aliran sungai masih terlihat tetapi relatif kecil dibandingkan dengan lebar sungai sesungguhnya. Sekitar $3 \mathrm{~km}$ diantaranya dari bibir pantai merupakan zona pengendapan yang dicirikan dengan morfologi yang landai dan lebar sungai yang semakin luas. Perbedaan elevasi cukup tajam di mana bagian hulu mempunyai elevasi $500 \mathrm{~m}-900 \mathrm{~m}$ dengan jarak sekitar $5 \mathrm{~km}$ dari muara sungai. Perbedaan morfologi nampak jelas terlihat. Bagian hulu berbukit bukit terjal dan nampak kenampakan triangular facet yang kemungkinan terbentuk akibat longsor purba. Lebar sungai berkembang dari beberapa meter di bagian hulu, puluhan meter di bagian tengah, dan berubah menjadi ratusan meter (termasuk dengan channel bar) di bagian hilir. Perubahan tersebut berjarak cukup dekat dari hulu yang sempit hingga hilir yang lebar. Kontras morfologi tersebut menyebabkan sungai ini sangat rentan banjir bandang bila ada terjadi longsor besar di salah satu lereng atau bukit di bagian hulu (Gambar 6).

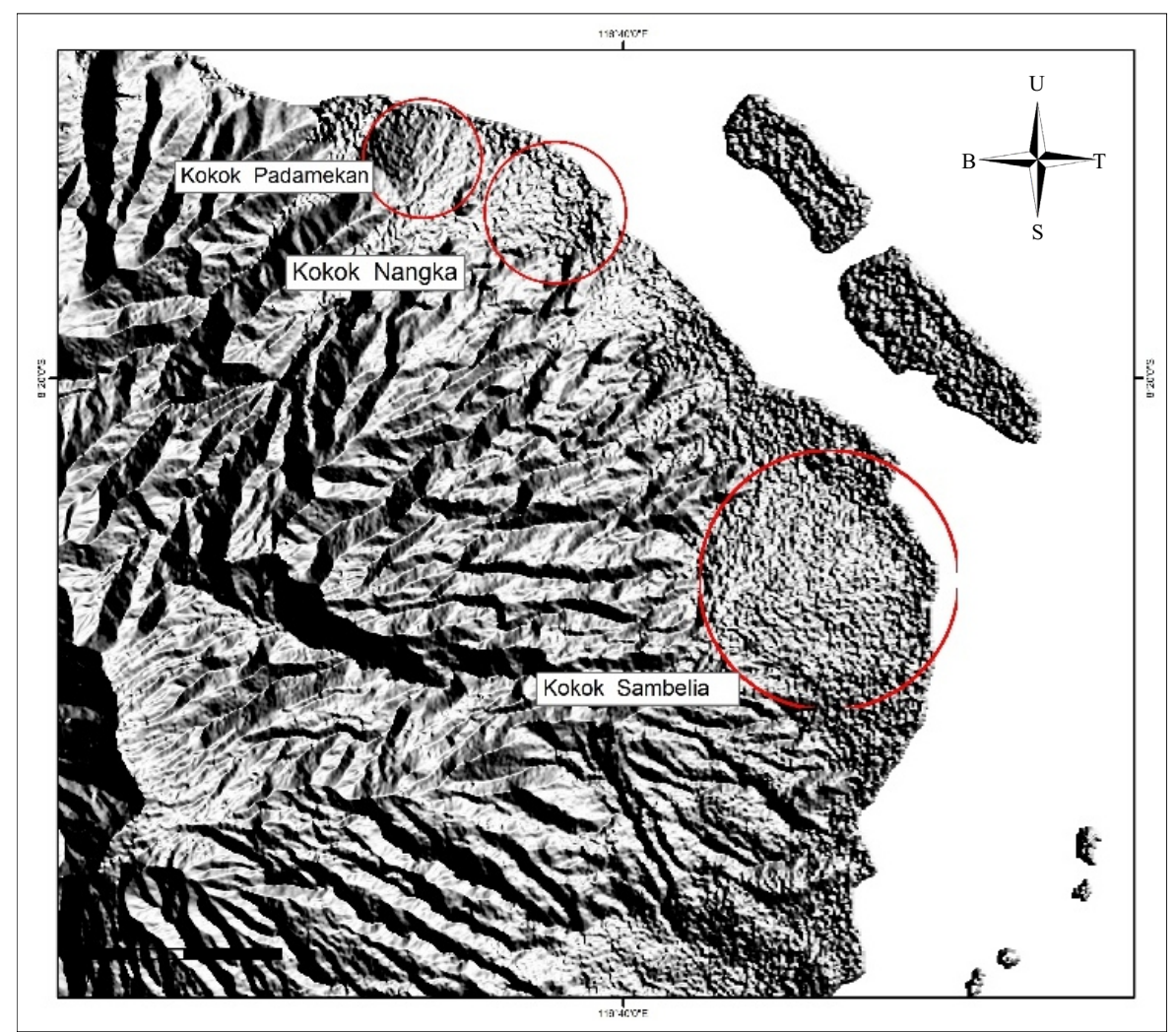

Gambar 5. Sungai sungai yang berpotensi banjir bandang di Sambelia (lingkaran merah : kipas aluvial/endapan aliran bahan rombakan). 


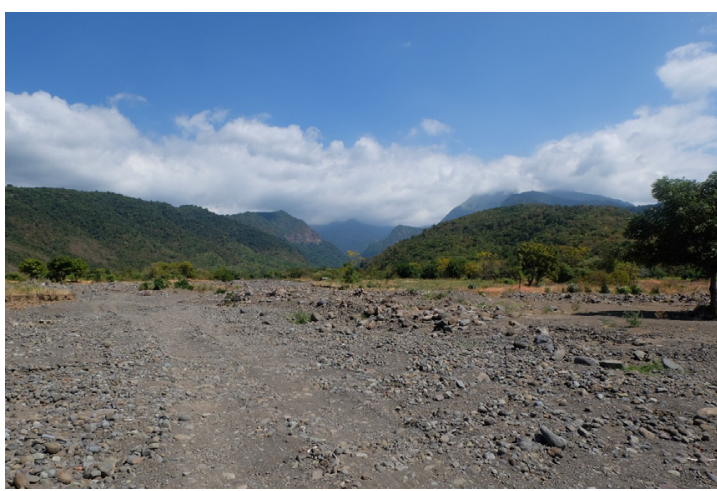

Gambar 6. Kokok Padamekan, terlihat kontras morfologi di bagian hulu atas yang rentan terjadi longsor.

Batuan di Kokok Padamekan secara umum adalah endapan aluvial dan batuan gunungapi tua berupa lava andesit, breksi, tuff. Endapan sungai terlihat jelas di bagian hilir dan tengah yang didominasi bongkah bongkah andesit hingga berukuran $2 \mathrm{~m}$. Sebagian besar batuan berbentuk butir subrounded hingga rounded yang menunjukkan bahwa batuan telah mengalami proses transportasi. Di beberapa sisi sungai dan channel bar terlihat endapan jatuhan piroklastik pumis (lapili dan tufa) yang kemungkinan berasal dari Gunung Rinjani. Endapan tersebut terlihat selaras dengan endapan sungai di bagian bawahnya. (Gambar 7).

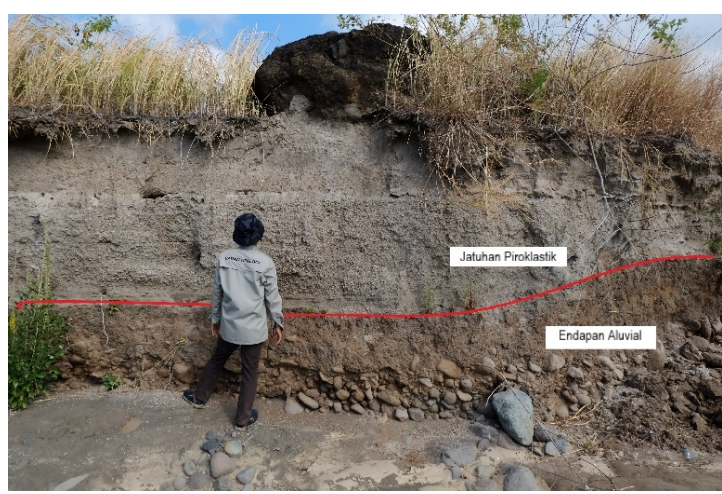

Gambar 7. Litologi di Kokok Padamekan, endapan jatuhan piroklastik di atas endapan aluvial.

Bagian tengah agak ke hulu ke daerah perbukitan, batuannya sudah berbeda. Pada bagian sisi sungai terlihat batuan yang menjadi pembentuk bukit bukit yang ada. Litologinya berupa lava andesit. Beberapa bagian nampak lapuk, tetapi bagian yang lain masih terlihat segar. Semakin ke hilir ke muara sungai, material bongkah-bongkah andesit masih teramati meskipun ukurannya tidak sebesar di bagian tengah. Kenampakan pantai juga berbeda. Hal ini terlihat dari adanya kontras pantai yang ada. Di bagian dekat muara pantainya cenderung berbatu. Sedangkan pantai di dekatnya sekitar $100 \mathrm{~m}$ ke sisi yang lain terlihat didominasi pasir. Kenampakan ini menunjukkan bahwa kejadian aliran bahan rombakan terdahulu pernah terjadi hingga mencapai bibir pantai.

Nangka terletak di tenggara Kokok Padamekan. Secara administratif Kokok Nangka masih berada di Desa Belanting. Pada tahun 2006, terjadi aliran bahan rombakan yang merobohkan Jembatan Belanting di sungai ini.

Secara umum karakter morfologinya tidak jauh berbeda dengan Kokok Padamekan. Di daerah hulu berupa perbukitan berlerang terjal dengan lembah sungai yang sempit. Sungai mengalir diantara 2 punggungan bukit yang terjal. Perbedaan elevasi juga sangat kontras dengan panjang sungai yang hanya sekitar $10 \mathrm{~km}$. Morfologi triangular facet sangat umum terlihat pada lereng lereng bukit yang mempertegas adanya longsor purba di daerah ini. Di bagian hulu sangat rentan membentuk bendung alam bila ada bagian lereng yang mengalami longsor dan menimbun sungai. Lebar sungai melebar hampir $100 \mathrm{~m}$ di dekat Jembatan Belanting. Semakin ke hilir banyak terbentuk channel bar yang membentuk percabangan sungai (braided stream). Kondisi sungai terlihat kering pada musim kemarau. Aliran kecil terlihat mengalir pada salah satu cabang anak sungai di dekat Jembatan Belanting.

Batuan penyusun di Kokok Nangka secara umum sama dengan yang dijumpai di Kokok Padamekan. Sungai dipenuhi dengan bongkah bongkah andesit berbagai macam ukuran. Bentuk butir terlihat sudah subrounded-rounded. Sedangkan di tepi sungai terlihat batuan penyusun berupa endapan aluvial. Endapan tersebut didominasi oleh fragmen andesit dan breksi mulai 
dari bongkah dan kerikil. Warna sudah memudar kecoklatan dengan warna segar adalah abu abu. Sortasi buruk dengan matriks berupa material pasir kasar. Fragmen endapan terlihat berbagai macam ukuran bahkan hingga bagian hilir. Ini menunjukkan kemungkinan bahwa endapan tersebut terbentuk akibat aliran bahan rombakan. Semakin ke bagian hulu di daerah bukit batuan penyusun berupa lava andesit. Warna abu abu secara umum dan berubah kecoklatan pada bagian yang lapuk. Tekstur porfiro afanitik hingga afanitik. Di beberapa bagian terlihat struktur kekar lembaran. Di beberapa bagian pada channel bar juga terlihat adanya endapan jatuhan piroklastik berupa pumis (lapili hingga tufa) yang menempel selaras di atas endapan sungai.

Pada bagian tengah sekitar $300 \mathrm{~m}$ ke arah hulu dari Jembatan Belanting, terdapat Sabo Dam yang dibangun setelah kejadian aliran bahan rombakan tahun 2006 (Gambar 8). Sabo Dam ini mempunyai tinggi sekitar 20-25 m dengan panjang sekitar $60 \mathrm{~m}$. Kehadiran dam ini sedikit banyak mengurangi kecepatan banjir yang terjadi. Dari beberapa kejadian banjir bandang yang terjadi dilaporkan tidak sebesar kejadian bencana tahun 2006. Meskipun beberapa rumah dan jalan ada yang terendam.

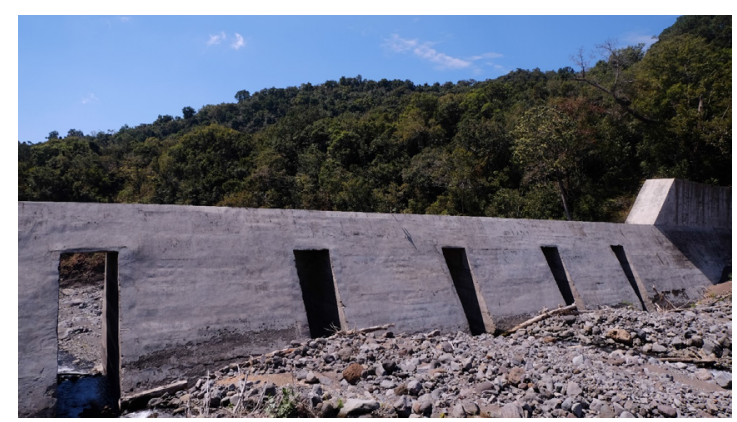

Gambar 8. Sabo Dam di Kokok Nangka.

Di bagian mendekati hulu sering dijumpai pohonpohon besar tumbang (Gambar 9). Kehadiran pohon-pohon besar ini bisa saja menjadi penyumbat sungai yang berkembang menjadi bendung alam. Selain itu, jejak longsor lama beberapa tahun terakhir juga terlihat di beberapa lereng (Gambar 10). Longsor pada lereng-lereng harus

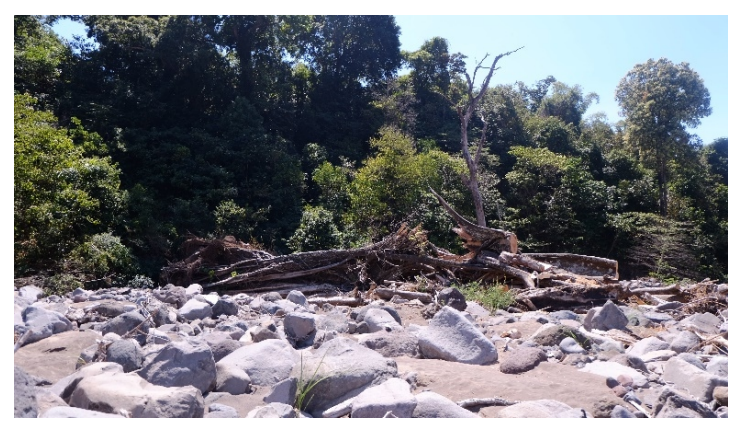

Gambar 9. Pohon tumbang di Kokok Nangka

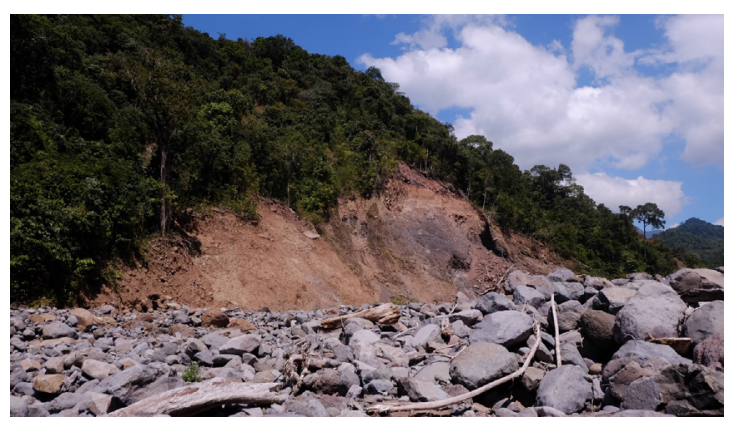

Gambar 10. Longsor lama di sisi aliran Kokok Nangka

diwaspadai karena meskipun longsornya kecil tetapi bila terus terjadi berkesinambungan, bisa saja endapannya terbawa air hujan dan bergabung membendung sungai menjadi bendung alam.

Kokok Sambelia terletak di Desa Sambelia. Berdasarkan pengamatan citra satelit terlihat kenampakan kipas aluvial (Gambar 5) yang sangat besar. Sebagian besar daerah Sambelia termasuk dalam bagian kipas aluvial ini. Di sepanjang jalan di daerah Sambelia terlihat bebatuan besar (bongkah-bongkah) (Gambar 11) terlampar bahkan hingga area persawahan. Ini menunjukkan kejadian banjir besar sering melanda daerah ini pada masa silam.

Karakter morfologi Kokok Sambelia yaitu sungainya ke hulu menyempit diapit dengan punggungan bukit berlereng terjal. Banyak channel bar yang berisi pepohonan besar. Namun, Kokok Sambelia di bagian tengah dan hilir lebar sungainya tidak selebar Kokok Nangka dan Padamekan.

Batuan penyusun di Kokok Sambelia secara umum adalah endapan aluvial. Bongkah bongkah andesit tersebar mengisi sungai yang cenderung 


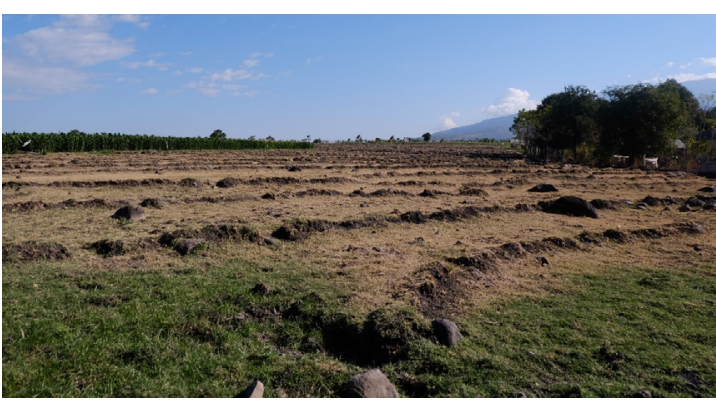

Gambar 11. Bebatuan besar di area sawah sebagai jejak adanya endapan banjir masa lalu.

kering di musim kemarau. Di beberapa bagian sisi sungai terlihat singkapan endapan aluvial berupa fragmen bongkah andesit dengan matrik pasir kasar, terlihat rapuh dan agak lapuk, tetapi di bagian agak ke hulu ditemukan pula yang masif. Sortasi buruk dan bentuk butir subrounded hingga rounded. Di bagian hilir endapan sungai ini di atasnya diendapkan endapan jatuhan piroklastik berupa tufa halus hingga kasar. Endapan ini berwarna abu-abu cerah, sortasi baik. Di bagian hulu batuannya tersusun campuran endapan alluvial, breksi, dan lava andesit.

Kokok Sambelia rentan aliran bahan rombakan karena potensi pohon-pohon besar yang tumbang yang tumbuh pada channel bar sungai di bagian hulu (Gambar 12). Pohon-pohon yang tumbang tersebut bisa saja menjadi bendung alam selain adanya longsor dan batu batu besar. Belum lagi potensi luapan aliran bahan rombakan yang bisa overflow karena daerah endapan atau tangkapan sungainya tidak selebar seperti pada Kokok Nangka dan Kokok Padamekan. Infrastruktur seperti jembatan juga rentan akibat banjir. Ini terbukti dengan sering terjadi

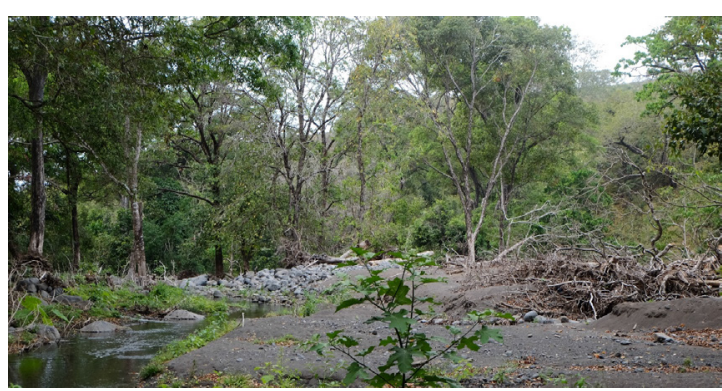

Gambar 12. Pepohonan pada channel bar yang berpotensi tumbang dan menjadi bendung alam. jembatan roboh atau rusak di Kokok Sambelia (Gambar 13).

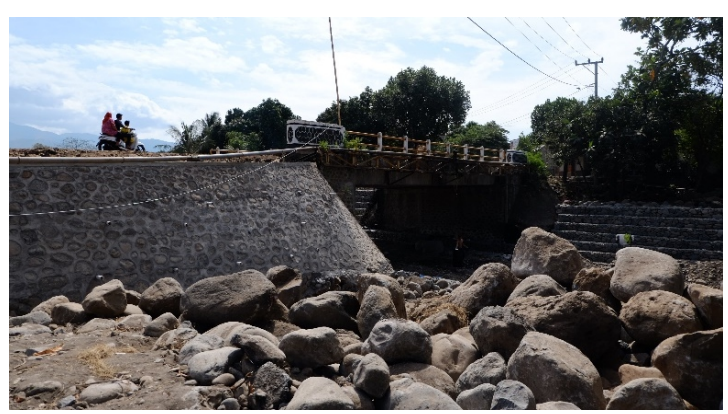

Gambar 13. Jembatan Sambelia, salah satu infrastruktur yang sering rusak akibat banjir

(Digital Elevation Model) adalah data digital yang menggambarkan geometri dari bentuk permukaan bumi atau bagiannya yang terdiri dari himpunan titik-titik koordinat hasil sampling dari permukaan dengan algoritma yang mendefinisikan permukaan tersebut menggunakan himpunan koordinat (Tempfli, 1991). DEM yang digunakan untuk pemodelan berupa Digital Surface Model (DSM) Terrasar dengan resolusi $9 \mathrm{~m}$. DEM harus diubah ke dalam format Arc ASCII (asc) agar dapat dipakai di RAMMS. Selain DEM, RAMMS juga membutuhkan data orthophoto untuk tampilan 2D. Data orthophoto untuk pemodelan ini menggunakan hillshade dari DEM. Beberapa sungai yang akan dimodelkan mempunyai Sabo Dam (bendungan) di alirannya yaitu Kokok Padamekan dan Kokok Nangka. Oleh karena itu, DEM perlu di-update dengan menambahkan data Sabo Dam pada DEM. Penambahan dam dapat dilakukan di dalam perangkat lunak RAMMS.

Pemodelan aliran bahan rombakan menggunakan RAMMS membutuhkan beberapa input parameter. Parameter yang digunakan di antaranya parameter friksi, volume, daerah inisiasi, debit aliran, dll. Parameter friksi pada RAMMS mengacu pada model friksi fluida Voellmy (Salm drr, 1993). Model ini membagi resistansi friksi menjadi 2 yaitu dry-Coulomb type friction $(\mu)$ dan viscous-turbulent friction $(\xi)$. Penentuan input parameter untuk $\mu$ dan $\xi$ dilakukan melalui kalibrasi dari beberapa kali pemodelan dari beberapa 
variasi nilai $\mu$ dan $\xi$. Kalibrasi ini perlu dilakukan karena simulasi aliran debris mempunyai komposisi yang bervariasi. RAMMS: Debris Flow; menggunakan model satu fase sehingga sulit dibedakan antara fase padat dan fase fluida dan material dimodelkan sebagai bulkflow. Kalibrasi sebaiknya dilakukan dengan pendampingan dari ahli aliran bahan rombakan.

Volume banjir bandang untuk input RAMMS dibedakan menjadi tiga yaitu volume 1000000 $\mathrm{m}^{3}, 2000000 \mathrm{~m}^{3}$ dan $3000000 \mathrm{~m}^{3}$. Nilai tersebut didapatkan melalui pendekatan volume daerah aliran sungai yang akan dimodelkan. Volume lebih dari $3000000 \mathrm{~m}^{3}$ menunjukkan hasil yang selalu overflow dari beberapa simulasi pemodelan, sehingga volume tersebut dianggap cukup untuk sebuah aliran bahan rombakan besar di Sambelia.

Daerah inisiasi adalah titik atau daerah yang dianggap sebagai awal mula banjir bandang. Titik yang dipilih secara umum adalah daerah pertemuan beberapa anak sungai yang sempit yang dihimpit punggungan bukit terjal yang sangat rentan terjadi longsor. Titik tersebut dipilih berdasarkan asumsi karena sulitnya menemukan daerah yang pernah menjadi bendung alam. Karakter inisiasinya menggunakan hydrograph karena mengikuti daerah aliran sungai yang cukup panjang.

Aliran bahan rombakan yang terjadi pada tahun 2006 dan disebabkan oleh tingkat curah hujan yang mencapai $676 \mathrm{~mm} /$ tahun sehingga debit air sungai mencapai $2838 \mathrm{~m} 3 /$ detik (Hidayani, 2015). Nilai debit inilah yang dipakai untuk input RAMMS. Untuk nilai kohesi dianggap nol karena lebih didominasi bongkah bongkah andesit atau dianggap cohesionless.

Dari beberapa simulasi awal pemodelan didapatkan nilai parameter untuk input pemodelan RAMMS Debris Flow di Sambelia sesuai Tabel 2.

Pemodelan RAMMS pada Kokok Padamekan dengan volume $1000000 \mathrm{~m}^{3}$ menghasilkan landaan maksimum mencapai 5,066 km dengan luas landaan $902745 \mathrm{~m}^{2}$. Sedangkan untuk volume $2000000 \mathrm{~m}^{3}$ hasil panjang maksimum
Tabel 2. Nilai Parameter untuk Pemodelan RAMMS

\begin{tabular}{|cc|}
\hline Volume & $1000000,2000000,3000000\left(\mathrm{~m}^{3}\right)$ \\
\hline$\mu$ & 0,01 \\
\hline$\xi$ & $700 \mathrm{~m} / \mathrm{s}^{2}$ \\
\hline $\mathrm{c}$ (Kohesi) & 0 \\
\hline Debit & $2838 \mathrm{~m} 3 /$ detik \\
\hline
\end{tabular}

landaan 6,836 km dengan luas landaan 1586304 $\mathrm{m}^{2}$. Untuk volume $3000000 \mathrm{~m}^{3}$ didapatkan panjang maksimum landaan yaitu 7,449 km dengan luas landaan $2725650 \mathrm{~m}^{2}$.

Pemodelan RAMMS untuk Kokok Nangka dengan volume $1000000 \mathrm{~m}^{3}$ didapati hasil panjang landaan maksimum mencapai $6,449 \mathrm{~km}$ dari titik inisiasi dengan luas landaan yaitu $1649403 \mathrm{~m}^{2}$. Untuk volume $2000000 \mathrm{~m}^{3}$ didapati hasil panjang landaan maksimum mencapai 7,295 km dengan luas landaan yaitu $3089016 \mathrm{~m}^{2}$. Sedangkan untuk volume $3000000 \mathrm{~m}^{3}$ hasil yang didapatkan untuk panjang landaan maksimum mencapai $8,045 \mathrm{~km}$ dengan luas landaan $4807836 \mathrm{~m}^{2}$.

Pemodelan RAMMS untuk Kokok Sambelia dengan volume $1000000 \mathrm{~m}^{3}$ didapati hasil panjang landaan maksimum mencapai $6,36 \mathrm{~km}$ dari titik inisiasi dengan luas landaan yaitu 1882845 $\mathrm{m}^{2}$. Untuk volume $2000000 \mathrm{~m}^{3}$ didapati hasil panjang landaan maksimum mencapai $6,608 \mathrm{~km}$ dengan luas landaan yaitu $3460401 \mathrm{~m}^{2}$. Sedangkan untuk volume $3000000 \mathrm{~m}^{3}$ hasil yang didapatkan untuk panjang landaan maksimum mencapai $8,027 \mathrm{~km}$ dengan luas landaan $7639515 \mathrm{~m}^{2}$.

Hasil pemodelan secara umum dapat dilihat pada tabel 3 dan gambar 14-16 berikut ini.

Tabel 3. Hasil Pemodelan RAMMS

\begin{tabular}{|c|c|c|c|}
\hline Sungai & $\begin{array}{c}\text { Volume } \\
\left(\mathbf{m}^{3}\right)\end{array}$ & $\begin{array}{c}\text { Panjang } \\
\text { Maksimum } \\
\text { Landaan (km) }\end{array}$ & $\begin{array}{c}\text { Luas } \\
\text { Landaan } \\
\left(\mathbf{m}^{2}\right)\end{array}$ \\
\hline \multirow{3}{*}{$\begin{array}{c}\text { Kokok } \\
\text { Padamekan }\end{array}$} & 1000000 & 5,066 & 902745 \\
\hline & 2000000 & 6,836 & 1586304 \\
\hline & 3000000 & 7,449 & 2725650 \\
\hline \multirow{3}{*}{$\begin{array}{c}\text { Kokok } \\
\text { Nangka }\end{array}$} & 1000000 & 6,449 & 1649403 \\
\hline & 2000000 & 7,295 & 3089016 \\
\hline & 3000000 & 8,045 & 4807836 \\
\hline \multirow{3}{*}{$\begin{array}{c}\text { Kokok } \\
\text { Sambelia }\end{array}$} & 1000000 & 6,36 & 1882845 \\
\hline & 2000000 & 6,608 & 3460401 \\
\hline & 3000000 & 8,027 & 7639515 \\
\hline
\end{tabular}




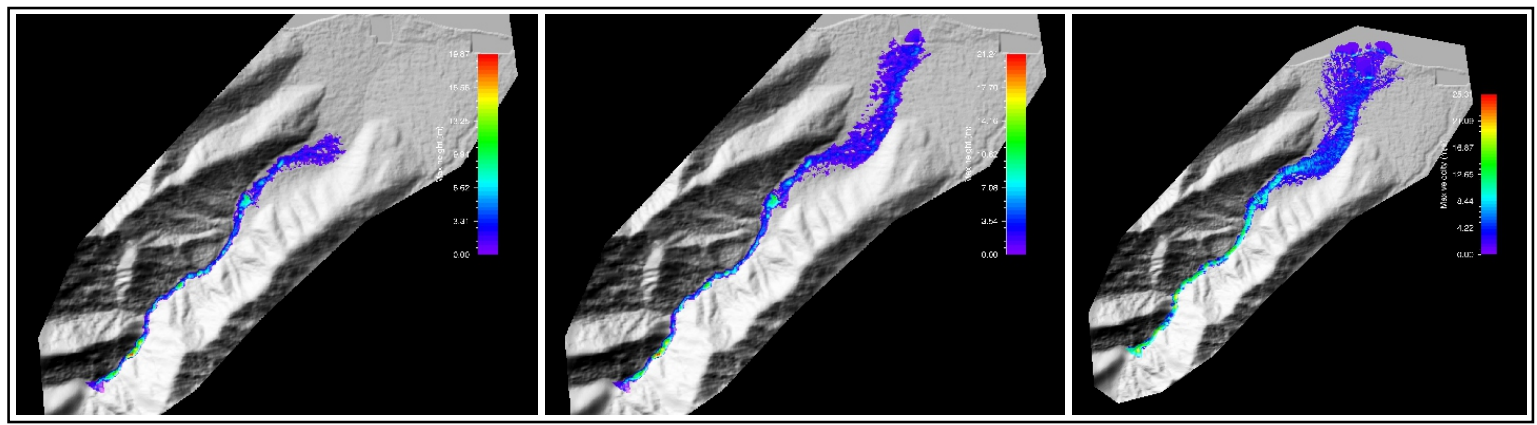

Gambar 14. Hasil Pemodelan RAMMS pada Kokok Padamekan. Dari kiri ke kanan: Volume 1000000 m³ $^{3} 2000000 \mathrm{~m}^{3}$, $3000000 \mathrm{~m}^{3}$.

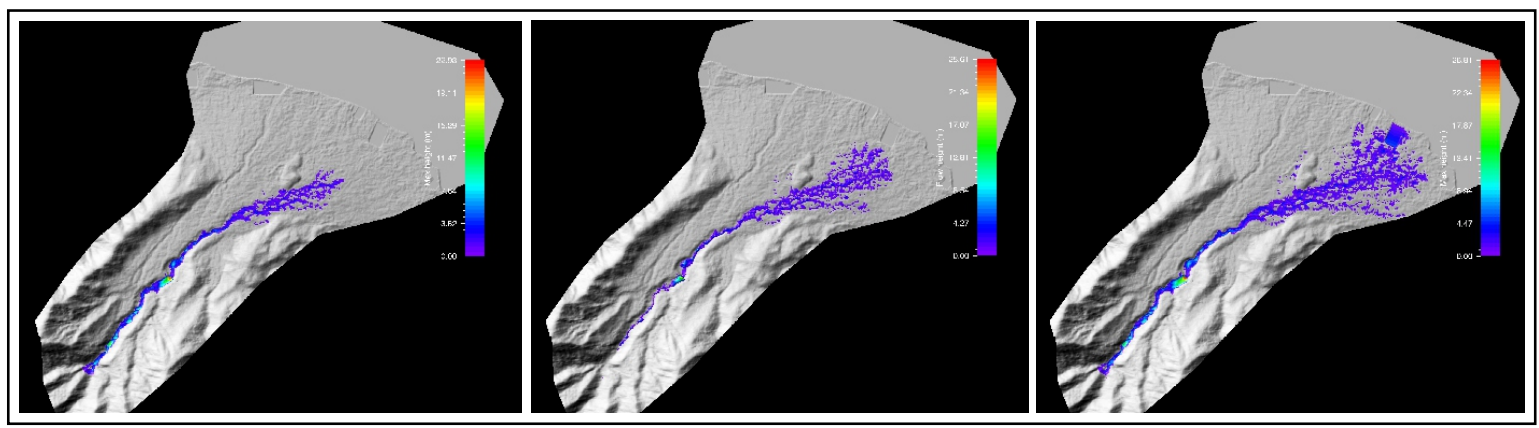

Gambar 15. Hasil Pemodelan RAMMS pada Kokok Nangka. Dari kiri ke kanan: Volume 1000000 m³ $^{3} 2000000$ m³, $^{3}$ $3000000 \mathrm{~m}^{3}$.
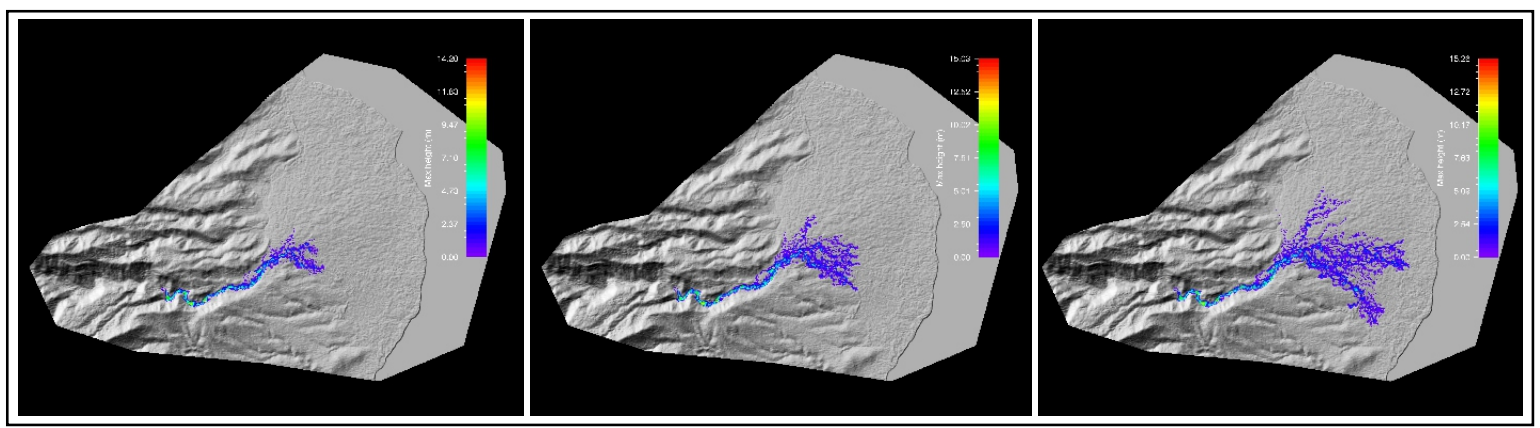

Gambar 16. Hasil Pemodelan RAMMS pada Kokok Sambelia. Dari kiri ke kanan: Volume $1000000 \mathrm{~m}^{3}, 2000000 \mathrm{~m}^{3}$, 3000000 .

Berdasarkan hasil pemodelan dengan tiga volume yang berbeda terlihat perbedaan yang cukup signifikan dari ketiga sungai. Volume lebih besar akan semakin luas landaannya. Pada Kokok Padamekan dengan volume 1000000 $\mathrm{m}^{3}$ panjang landaan hanya $5,066 \mathrm{~km}$ dengan sedikit overflow pada Sabo Dam. Untuk volume $2000000 \mathrm{~m}^{3}$ landaannya sudah overflow cukup besar tapi belum sampai bibir pantai/ muara. Sedangkan untuk volume $3000000 \mathrm{~m}^{3}$ landaannya sudah mencapai pantai bahkan over- flow yang sangat besar. Untuk Kokok Nangka dengan ketiga volume tersebut landaannya lebih luas dan panjang karena titik inisiasinya lebih jauh. Namun, untuk volume $3000000 \mathrm{~m}^{3}$ pada Kokok Nangka tidak mencapai bibir pantai, hanya landaannya lebih melebar daripada Kokok Padamekan. Untuk Kokok Sambelia, hasil pemodelannya menunjukkan hal yang berbeda dibandingkan dengan Kokok Padamekan dan Kokok Nangka. Pada Kokok Sambelia dengan volume $3000000 \mathrm{~m}^{3}$ landaannya paling jauh dan 
melebar membentuk kipas aluvial yang cukup besar dengan luas landaan 763,9 ha. Kokok Sambelia memang mempunyai lebar sungai yang lebih kecil daripada Kokok Nangka dan Padamekan. Namun, lebar sungai yang kecil ini justru berpotensi menjadi overflow paling besar dan berbahaya daripada sungai yang lainnya. Hal ini diperparah dengan jarak pemukiman yang tidak terlalu jauh dari sungai dibanding dengan Kokok Nangka dan Padamekan. Hasil pemodelan juga menunjukkan Kokok Sambelia mempunyai panjang landaan maksimum dan luas landaan paling besar dibandingkan dengan sungai lainnya.

Hasil pemodelan RAMMS kemudian dibandingkan dengan Peta Aliran Bahan Rombakan yang terdapat pada Peta Zona Kerentanan Gerakan Tanah (ZKGT) Pulau Lombok (Luthfi drr, 2008) (Gambar 17). Secara umum zona landaan berarah sama sepanjang aliran sungai. Untuk Kokok Padamekan, hasil pemodelan RAMMS mirip dengan Peta Aliran Bahan Rombakan.

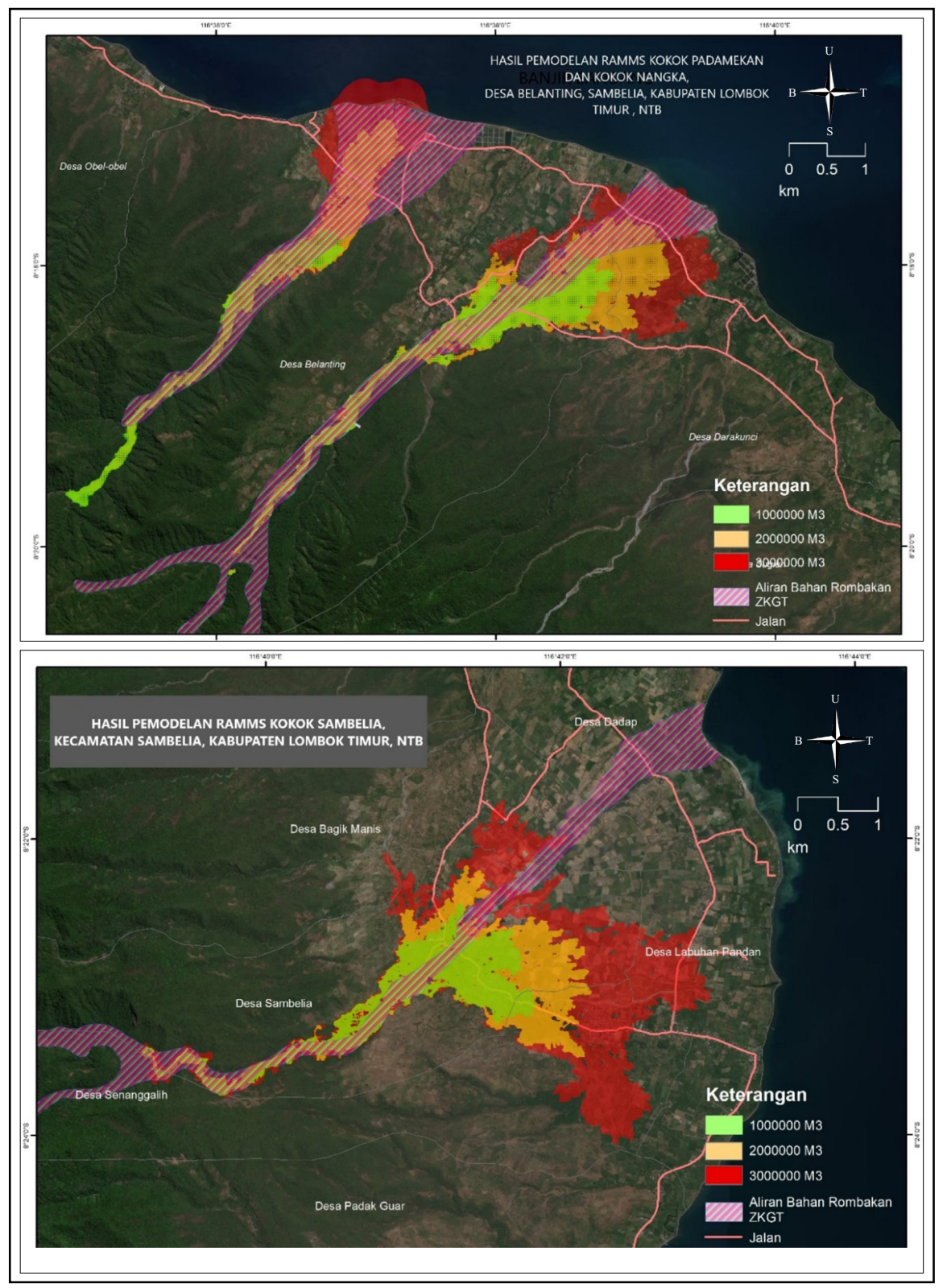

Gambar 17. Hasil Pemodelan RAMMS Kokok Paamekan, Kokok Nangka, dan Kokok Sambelia ditampalkan dengan zona aliran bahan rombakan pada ZKGT Lombok Timur. 
Perbedaan terlihat pada arah landaan akhir di mana bagian zona aliran bahan rombakan lebih luas dan melebar dari RAMMS. Sedangkan untuk Kokok Nangka dan Kokok Sambelia perbedaannya sangat signifikan. Hasil pemodelan RAMMS menunjukkan zona landaan yang cenderung overflow atau melebar membentuk kipas aluvial yang lebih luas. Sedangkan untuk Peta Aliran Bahan Rombakan pada ZKGT zonasinya cenderung lurus dan tidak melebar. Hasil pemodelan RAMMS ini pada akhirnya dapat digunakan untuk kajian Zonasi Aliran Bahan Rombakan untuk pembuatan atau revisi aliran bahan rombakan pada peta ZKGT. Hal ini karena Peta Aliran Bahan Rombakan pada peta ZKGT dibuat sangat subjektif melalui interpretasi dan tanpa simulasi.

Berdasarkan hasil pemodelan aliran bahan rombakan menggunakan RAMMS dapat diketahui daerah atau desa yang terdampak langsung bila suatu saat banjir bandang terjadi. Kokok Padamekan di Desa Belanting menjadi daerah yang harus diwaspadai karena ujung aliran banjir bandang melewati desa ini. Masyarakat yang beraktivitas di bagian hilir sungai juga harus waspada pada radius $0.5 \mathrm{~km}$ dari sungai karena aliran yang mungkin melebar. Untuk Kokok Nangka hasil pemodelan bertampalan dengan Desa Belanting bagian timur dan Desa Darakunci. Pemukiman di dekat aliran sungai dengan radius $700 \mathrm{~m}$ agar selalu waspada. Di dekat bagian hilir sungai ini juga terdapat Sekolah Polisi Negara (SPN) yang rawan terdampak. Sedangkan untuk Kokok Sambelia, hasil pemodelan menunjukkan daerah rawan untuk Desa Sambelia, Desa Labuhan Pandan, sebagian kecil Desa Bagik Manis, Desa Senanggalih, dan mungkin Desa Dadap jika asumsi volume banjir lebih dari $3000000 \mathrm{~m}^{3}$. Pemukiman pada radius $1 \mathrm{~km}$ dari aliran sungai juga harus waspada karena overflow Kokok Sambelia sangat lebar dan berpotensi meluas dibandingkan dengan Kokok Nangka dan Padamekan. Infrastruktur seperti jalan dan jembatan perlu tinjauan khusus agar tidak terjadi kerusakan fatal yang dapat mengganggu kegiatan masyarakat. Aktivitas manusia di sepanjang sungai seperti bercocok tanam, berkebun, dan tambak harus waspada saat musim hujan.

Untuk mitigasi bencana banjir bandang, dengan adanya pemodelan ini dapat diidentifikasi daerah rawan atau bahaya. Dengan mengetahui zona-zona rentan dapat membantu meningkatkan kewaspadaan masyarakat akan potensi bencana banjir bandang atau aliran bahan rombakan. Selain itu, pembangunan dan revitalisasi Sabo Dam perlu dilakukan untuk mengurangi energi atau menghambat aliran jika sewaktu-waktu terjadi. Khusus untuk Kokok Sambelia perlu diwaspadai khusus karena pada sungai ini belum mempunyai Sabo Dam seperti pada Kokok Padamekan dan Kokok Nangka. Hal lainnya yang mungkin bisa dilakukan adalah penguatan konstruksi seperti jembatan agar tidak mudah roboh diterjang banjir. Jembatan roboh akan memutus jaringan transportasi di Sambelia yang akan sangat mengganggu aktivitas ekonomi masyarakat.

\section{KESIMPULAN}

Kokok Padamekan, Kokok Nangka, dan Kokok Sambelia merupakan sungai-sungai di Kecamatan Sambelia yang rentan dan berpotensi tinggi terjadi aliran bahan rombakan.

Hasil pemodelan aliran bahan rombakan menggunakan perangkat lunak RAMMS menunjukkan zonasi landaan banjir dengan luasan maksimum untuk volume $3000000 \mathrm{~m}^{3}$ pada Kokok Padamekan, Kokok Nangka, dan Kokok Sambelia berturut - turut yaitu $2725650 \mathrm{~m}^{2}$, $4807836 \mathrm{~m}^{2}$, dan $7639515 \mathrm{~m}^{2}$.

Hasil pertampalan antara Aliran Bahan Rombakan pada Peta ZKGT (Luthfi drr, 2008) dan pemodelan RAMMS menunjukkan perbedaan yang signifikan antara pemodelan RAMMS yang menunjukkan detail yang lebih baik dengan menunjukkan potensi adanya overflow daripada aliran bahan rombakan ZKGT

Hasil pemodelan RAMMS dapat mengidentifikasi daerah atau desa yang rawan terdampak 
bencana yaitu Desa Belanting, Desa Darakunci, Desa Sambelia, Desa Labuhan Pandan, sebagian kecil Desa Bagik Manis, Desa Senanggalih.

\section{UCAPAN TERIMA KASIH}

Terima kasih untuk Sdr. Bagus Syulthon, Sdr. Tumpal Sinaga, dan Bpk. Mutaharlin atas bantuan selama kegiatan lapangan berlangsung di Kabupaten Lombok Timur, Nusa Tenggara Barat.

\section{DAFTAR PUSTAKA}

Andi Mangga, S., Atmawinata, S., Hermanto, B., Setyogroho, B., dan Amin, T.C., 1994. Peta Geologi Lembar Lombok, Nusa Tenggara. Pusat Penelitian dan Pengembangan Geologi, Indonesia.

Christen, M., Kowalski, J., \& Bartelt, P., 2010. RAMMS: Numerical simulation of dense snow avalanches in three-dimensional terrain. Cold Regions Science and Technology, 63 (1-2), 1-14. DOI: 10.1016/j. coldregions.2010.04.005

Darsoatmodjo. A dan Rukmana. N., 2012. Laporan Penyelidikan Tanggap Darurat Bencana Gerakan Tanah Kecamatan Sambelia, Kabupaten Lombok Timur, Nusa Tenggara Barat. Pusat Vulkanologi dan Mitigasi Bencana Geologi, Bandung.

Hidayani, Nurul., 2015. Pemetaan Rawan Banjir Bandang Daerah Aliran Sungai Sambelia Kecamatan Sambelia Kabupaten Lombok Timur NTB. Tugas Akhir (tidak dipublikasikan. Universitas Gadjah Mada, Yogyakarta.

Kowalski, J., 2008. Two-Phase Modeling of Debris Flows. PhD Thesis, Swiss Federal Institute of Technology, Zurich.
Luthfi, A., 2008. Laporan Pemetaan Zona Kerentanan Gerakan Tanah Pulau Lombok Bagian Timur dan Sekitarnya, Nusa Tenggara Barat. Pusat Vulkanologi dan Mitigasi Bencana Geologi, Bandung.

Purnomo, H., 2006. Laporan Tanggap Darurat Bencana Gerakan Tanah Kecamatan Sambelia, Kabupaten Lombok Timur, Nusa Tenggara Barat. Pusat Vulkanologi dan Mitigasi Bencana Geologi, Bandung.

Quan Luna, B., 2007. Assesment and modelling of two lahars caused by "Hurricane Stan" at Atitlan, Guatemala, October 2005. M. Sc. Thesis, University of Oslo, Oslo.

Salm, B., 1993. Flow, flow transition and runout distances of flowing avalanches. In: Annals of Glaciology 18, 221-226. DOI: 10.3189/S0260305500011551

Tempfli, K., 1991. "DTM and differential modelling In: Proceedings ISPRS and OEEPE joint workshop on updating data by photogrammetric records". Oxford, England/ ed. by P.R.T. Newby. OEEPE publication :27, pp. 193-200.

Varnes, D.J., 1978. Slope movement types and process, Special Report 176; Landslides; Analysis and Control, Eds: R.L. Schuster dan R.J. Krizek, Transport Research Board, National Research Council, Washigton, DC

Wilford, D.J., Sakals, M.E., Innes, J.L., Sidle, R.C. and Bergerud, W.A., 2004. Recognition of Debris Flow, Debris Flood and Flood Hazard through Watershed Morphometrics. Landslides, 1, p.61-66. DOI: $10.1007 / \mathrm{s} 10346-003-0002-0$ 